Dossiê: Desafios teológicos do Pluralismo Religioso - Artigo original (c)

DOI - 10.5752/P.2175-5841.2015v13n40p1955

\title{
Teologia sob o signo da travessia: rumo a uma teologia intercultural
}

\section{Theology under the sign of crossing: towards an intercultural theology}

\author{
Sinivaldo Silva Tavares*
}

\begin{abstract}
Resumo
Mercado, Tecnociência e Mídia, interligados, constituem eficiente engrenagem a movimentar o mundo em que vivemos. Esta engrenagem potencializou-se nos últimos tempos por causa de três grandes transformações: da economia de mercado à sociedade de mercado, da técnica como instrumento à emergência da Tecnociência como horizonte e, por fim, da comunicação como meio à Mídia como cenário. Interpelada por esta situação, a teologia toma consciência da necessidade de se submeter a uma transformação intercultural. Ela elege o intercultural como seu objeto formal, distanciando-se criticamente do paradigma moderno da História, cenário das principais correntes teológicas do século XX. O intercultural é assumido, portanto, como "lugar teológico": perspectiva sob a qual abordar seus vários temas. Esta é, no final das contas, a condição para que a teologia intercultural contribua responsavelmente com nossa época, caracterizada pela indigência do pensamento. Ela convida-nos à tessitura de um saber como cuidado e como reconhecimento e rememora-nos dimensões próprias da Linguagem como mediação da existência humana e da vida em geral.
\end{abstract}

Palavras-chave: Mercado. Tecnociência. Mídia. Teologia intercultural. Linguagem.

\begin{abstract}
The Market, Technoscience, and the Media, all interconnected, constitute an efficient gearing that moves the world in which we live. This network was reinforced by three great transformations: the move from a market economy to a market society, from technology as an instrument to the emergence of Technoscience as a horizon, and finally the transformation from communication as a means to the media as a setting. Questioned by this new situation, theology becomes conscious of the necessity to submit itself to an intercultural transformation. It chooses the intercultural as its formal object of study, distancing itself from the modern paradigm of History, the setting of the principal theological currents of the $20^{\text {th }}$ century. The intercultural, then, is assumed as a theological place: a perspective from which various ideas can be studied. This is the condition by which an intercultural theology can contribute responsibly to our age, one that regrettably manifests penury of thinking. This theological approach invites us to consider knowledge as a texture of care and as recognition, and it reminds us of the very dimensions of Language as mediation of human existence and of life in general.
\end{abstract}

Keywords: Market. Technological Science. Media. Intercultural theology. Language.

Artigo recebido em 19 de outubro de 2015 e aprovado em 09 de dezembro de 2015.

* Doutor em Teologia Sistemática pela Pontificia Università Antonianum (1998), professor da Faculdade Jesuíta de Filosofia e Teologia FAJE, e do Instituto Santo Tomás de Aquino - ISTA. País de origem: Brasil. E mail: freisinivaldo@gmail.com 


\section{Introdução}

Habitamos um mundo extremamente complexo. O Mercado, a Tecnociência e a Midia constituem cenários nos quais se dão os vários âmbitos da experiência humana. A Tecnociência tornou-se horizonte de compreensão do ser humano em relação ao mundo e a si próprio. Não apenas nossos estilos de vida, nosso modo de trabalhar e viver, são condicionados pela técnica, mas também nossa identidade mais profunda. Testemunhamos ainda o fenômeno da "mercantilização da vida" produzido pelo mercado que vai se impondo como único cenário de nossa trama civilizacional atual. Nossos fluxos vitais se tornam mercadoria de consumo e de descarte. Por fim, verifica-se, em nossos dias, uma transformação deveras significativa. Hoje, falamos em Mídia e não mais em Meios de Comunicação Social (MCS). O termo Mídia nos remete a um horizonte a partir do qual compreender a totalidade dos fenômenos, uma autêntica mundividência.

Há uma interconexão que atravessa a totalidade dos fenômenos. Por esta razão, torna-se cada vez mais difícil captar as questões da civilização atual, que se revelam sempre mais em seu caráter multidimensional, com um saber compartimentado e com uma lógica linear. Somos vítimas de uma inadequação entre o saber e a realidade. Como desconstruir essa cultura da funcionalidade e da mercantilização que tem fortemente caracterizado as relações no mundo em que vivemos? Como seguir alimentando mentalidades e atitudes que encarnam uma violência cabal a nós e às demais criaturas? Como desconstruir os processos de desumanização e desnaturalização, ambos produzidos pela “tecnificação", "mercantilização" e "midiatização" da vida? Como, enfim, seguir submetendo-nos a um saber que se esgota na instrumentalidade e que, portanto, se revela incapaz de nos remeter às questões do sentido e de nos conduzir pelos meandros sutis das sendas da transcendência?

$\mathrm{Na}$ tentativa de acolher as questões postas acima, problematizando-as, a teologia cristã tem se colocado em permanente estado de "travessia". E, ao longo dessa travessia, ela tem advertido a necessidade de se submeter a um processo de 
transformação intercultural que atinja suas próprias raízes. Essa seria a condição para que a teologia contribua de maneira responsável ao diálogo acerca das questões que nos ocupam nesse início de século XXI. Daí a oportunidade de se elaborar uma teologia que seja, para todos os efeitos, intercultural: um discurso em que o intercultural é assumido como perspectiva e método e não apenas como objeto de estudo.

\section{Uma cumplicidade entre Mercado, Tecnociência e Midia}

O paradigma hegemônico do mundo em que vivemos é o resultado de uma cumplicidade entre Mercado, Tecnociência e Mídia. Compreendemos paradigma em seu sentido amplo, tal como Th. Khun o define na resposta à discussão com a Escola de Viena e com K. Popper: conjunto de modelos ou de padrões a partir dos quais a sociedade atual se orienta e organiza o conjunto de suas relações (KUHN, 1996). Empregamos o termo paradigma, portanto, no sentido de um sistema disciplinado mediante o qual organizamos nossa relação conosco mesmos, com as demais pessoas e com o conjunto da realidade na qual estamos inseridos.

A caracterizar, portanto, o paradigma hegemônico seria a estreita relação entre três transformações em curso no seio da civilização contemporânea: da economia de mercado à sociedade de mercado, da técnica como instrumento à emergência da Tecnociência como horizonte e da comunicação como meio à Mídia como cenário. Essas três transformações compõem a engrenagem que, por sua vez, põe em movimento a civilização contemporânea em seu tríplice processo: "mercantilização", "tecnificação" e "midiatização" da vida (TAVARES, 2014, p.384$398) .{ }^{1}$

\footnotetext{
${ }^{1}$ Repropõe-se aqui de forma condensada o que em outra ocasião fizemos de maneira mais ampla e detalhada (TAVARES, 2014, p. 384398).
} 


\subsection{Mercantilização da vida}

No primeiro caso, assistimos a uma grande transformação deflagrada já no início do século passado por K. Polanyi (POLANYI, 2000). As leis de mercado, que antes se restringiam ao âmbito da economia, passaram a regular a vida social na sua totalidade. Para descrever esse fenômeno cunharam-se expressões como: "mercantilização ou financeirização da vida", "absolutização do mercado" e etc (LIPOVETSKY, 2006; BAUMAN, 2008; ASSMANN; HINKELAMMERT, 1989; MO SUNG, 1989). Essas expressões, apesar de fortes, querem chamar nossa atenção para o fato de que nossos fluxos vitais são, nessa nova configuração, reduzidos impiedosamente a simples mercadorias de consumo e de descarte.

Há autores que sustentam que ingressamos assim em nova fase do Capitalismo ocidental: capitalismo de consumo. Em tal contexto, compreende-se a busca frenética por mercantilizar tudo, mediante o exacerbado inflacionamento das mercadorias visando ao consumo cada vez maior. Em sua nova fase, portanto, interessa ao capitalismo a produção de subjetividades consumidoras. E para incrementar o consumo e o apetite dos sujeitos consumidores é imprescindível que se invista no "fetichismo da mercadoria".

Tais processos têm se verificado sob o pressuposto da crescente supremacia do Mercado na administração dos fluxos vitais. Em nossos dias, tem se concebido e definido a vida como produto, uma simples mercadoria. Numa palavra, a vida tem se tornado mera invenção humana. E isso graças à inaudita capacidade do capitalismo do século XXI de operar um autêntico seqüestro simbólico das forças vitais. Ele não apenas captura tais forças como também consegue reciclar as resistências a esse seqüestro mediante a produção de slogans publicitários e mercadorias a serem consumidas. Até mesmo nossas bandeiras alternativas tem se tornado objeto de publicidade e, conseqüentemente, reduzidas a mercadorias sedutoras. 
Com base em tais análises, o capitalismo neoliberal estaria ultimando sua hegemonia global. Na medida em que vem conseguindo transformar a vida e, portanto, também os valores e símbolos culturais em mercadoria de consumo e de descarte, o capitalismo neoliberal tem consolidado sua hegemonia sobre nossa inteira civilização.

\subsection{Tecnificação da vida}

No mundo caracterizado pelo paradigma mecanicista moderno, a técnica era utilizada pelo ser humano como instrumento privilegiado na consolidação de seu saber como poder. Com razão, se dizia que a técnica nada mais era que ciência aplicada. De fato, a técnica se prestava, na condição de instrumento, a esse domínio do sujeito pensante sobre os demais seres considerados meros objetos mensuráveis. Concebida como simples instrumento, a técnica era vista como emanação do sujeito, vale dizer, extensão de seus membros visando a potencialização de seu domínio sobre as coisas.

Testemunhamos em nossos dias uma autêntica virada epocal: da idade da técnica para a era da Tecnociência. De mero instrumento de dominação à disposição do ser humano, qual era a técnica, percebemos que a Tecnociência tornou-se horizonte último no interior do qual se desvelam todos os âmbitos da experiência. Cunhou-se o termo "tecnosfera" para exprimir uma espécie de horizonte no interior do qual se produzem novas mentalidades e visões de mundo. Supera-se, por exemplo, aquela visão mecanicista e geométrica da física clássica e sua função domesticadora. Agora, na era da Tecnociência, a natureza é decomposta e, afinal, recriada segundo os moldes da ciência informática e da biologia molecular. Em outras palavras, as novas tecnologias não são mais meros instrumentos a serviço do ser humano na perseguição de determinados fins. Elas se tornaram, para todos os efeitos, produtoras de necessidades das quais o ser humano se torna cada vez mais dependente. 
O ser humano, nas contundentes palavras do filósofo italiano, Umberto Galimberti, "não é mais sujeito, mas algo disposto no horizonte desvelado pela Tecnociência, que é, afinal, o que decide o modo de ele se perceber, sentir, pensar e projetar" (GALIMBERTI, 2006, p. 383). O ser humano não é mais capaz de se perceber fora do mundo disposto pela Tecnociência, uma vez que ela se tornou o ambiente no qual o ser humano chega ao conhecimento de si. Por essa razão, justifica-se o uso do termo "Tecnociência" em vez de "técnica" simplesmente ou do adjetivo "científico-técnico". A Tecnociência tornou-se o horizonte de fundo dentro do qual a própria ciência encontra ou não sua legitimidade (GALIMBERTI, 2006, p. 391-393).

Considerando, enfim, que a Tecnociência, em nossos dias, se tornou horizonte imprescindível de compreensão do ser humano em relação ao mundo e a si próprio, então talvez fosse o caso de redirecionarmos aquela pergunta incontornável: não mais o que nós poderemos fazer com a tecnologia, mas o que as tecnologias podem fazer de nós?

\subsection{Mediatização da vida}

No que concerne mais especificamente à Mídia, testemunhamos uma verdadeira transformação. Na realidade, passamos de uma situação marcada pelos "meios" de comunicação social a outra caracterizada pela forte presença da Midia. No primeiro caso, tratava-se, de fato, de "meios" através dos quais eventuais emissores transmitiam notícias ou informações a determinados receptores. Nesse caso, a comunicação se reduzia a canais através dos quais a mensagem era transmitida por um emissor a um ou mais receptores. A Mídia, hoje, constitui um verdadeiro horizonte a partir do qual e no interior do qual são produzidas e não apenas transmitidas todas as possíveis informações. Diz-se, inclusive, que o que não é noticiado na Mídia não existe. Isso significa que o que não circula no horizonte da Mìdia não tem sequer direito de cidadania no mundo de hoje. 
Mesmo ostentando uma pretensa neutralidade asséptica, a Mídia não transmite informações de forma objetiva. No ato mesmo da transmissão ela constrói realidades. E ao fazê-lo, ainda que de maneira sutil, trai sua posição face ao que transmite. A Mídia se tornou, ademais, um mundo fora do qual não se pode mais viver. Não se pode mais prescindir desse mundo midiático. Tem se tornado impossível uma experiência diferente da proposta pela Mídia que, ao transmitir, constrói fatos e situações mediante sua interpretação interessada.

Falávamos acima de um processo de fetichização das mercadorias. A Mídia tem desempenhado uma função importantíssima nesse processo de fetichização. E a combinação entre Mercado e Mídia tem se revelado profundamente eficiente; os interesses escusos do Mercado são veiculados na Mídia em seu caráter profundamente sedutor. Excelentes estudos têm mostrado uma forte cumplicidade entre Mídia e Mercado na criação e manutenção dos processos descritos acima, tais como: "absolutização do Mercado", "mercantilização da vida", "fetichização da mercadoria" (MOREIRA, 2012; MOREIRA; LEMOS; QUADROS, 2012; ASSMANN; HINKELAMMERT, 1989; MO SUNG, 1989).

\section{Teologia intercultural: origem e propósitos}

Para compreender melhor os propósitos da Teologia Intercultural é necessário conhecer sua origem, pois afinal, nenhum pensamento surge do nada nem cai do céu como um pára-quedas. A origem remota da Teologia intercultural é o universo teológico do século XX na sua conhecida pluralidade de correntes. Preocupação comum a todas as correntes teológicas do século passado é corresponder às interpelações oriundas do Iluminismo. Seu contexto próximo é a ruptura provocada pela TdL latino-americana e, sucessivamente, pelas demais teologias contextuais. Assim, será mais fácil compreender os dissensos e as críticas movidas pela Teologia intercultural ao paradigma moderno da historicidade. E, 
uma vez conhecidos os dissensos e as críticas, se compreenderão melhor as prospectivas oferecidas pela teologia intercultural.

\subsection{A História: pano de fundo das teologias do século XX}

O que caracteriza grosso modo as distintas correntes teológicas surgidas no século XX é sua preocupação em “acertar o passo da história”. As interpelações postas de forma contundente pelo Iluminismo provocaram nas teologias cristãs a consciência de um duplo descompasso: irrelevância e anacronismo. E o efeito dessa consciência foi descobrir-se numa espécie de limbo, uma situação intermediária e fechada em si mesma. Por um lado, a teologia cristã se descobre aquém dos novos desafios postos pela situação atual. Por outro, ela se reconhece alheia às próprias fontes. Na origem deste despertar de consciência encontra-se a emergência da historicidade como paradigma hegemônico da Modernidade ocidental. Por essa razão, denominador comum de todas as formas de teologia que surgiram no século XX é a assunção da História como paradigma.

Pode-se afirmar que o leitmotiv das teologias do século passado é a simultaneidade entre abertura ao tempo presente e volta às origens. No início do século passado, M.-D. Chenu expunha em modo sistemático as linhas características da reforma da teologia almejada no recém-constituído escolasticado dos Dominicanos, em Le Saulchoir na Bélgica: afirmação do primado do dado revelado, assunção da crítica bíblica e histórica, tomismo aberto, atenção aos problemas do próprio tempo. Ainda no mesmo opúsculo, Chenu propunha a articulação da "fé in statu scientiae", em sua dupla função positiva e especulativa, com a "fé solidária com o próprio tempo" (CHENU, 1937). Expressão dessa mesma preocupação é o título por ele dado a uma de suas principais obras, publicada em dois volumes: La Parole de Dieu. 1. La foi dans l'intelligence; 2. L'Èvangile dans le temps (CHENU, 1964).

Anos mais tarde, em um artigo programático da assim chamada "Nouvelle Théologie”, publicado na revista Ètudes, sob o título de "Les orientations presentes 
de la pensée religieuse”, J. Daniélou traçava as diretrizes da renovação da teologia: 1) o retorno às fontes (Escrituras, Padres da Igreja, Liturgia); 2) o contato com as correntes do pensamento contemporâneo; 3) o contato com a vida (DANIÉLOU, 1946, p. 5-21).

É precisamente nesse contexto de antecipações, resistências, recuos e avanços que se convoca e se celebra o Concílio Vaticano II. O tão falado aggiornamento querido e proposto por João XXIII é expressão da consciência do anacronismo e da conseqüente irrelevância da Igreja e da teologia face aos novos e urgentes apelos do mundo de então. A urgência deste aggiornamento suscitou a "volta às fontes" ou o "retorno às origens" como potencialização da correspondência aos apelos do mundo dos anos 60 do século passado. Essa consciência está presente já na convocação do Concílio embora se explicite ainda mais na Alocução de abertura do Vaticano II, proferida por João XXIII: a Gaudet Mater Ecclesia. Emblemático, nesse sentido, o fato que a Coleção de Teologia, em vários volumes temáticos, elaborada imediatamente após o Vaticano II e sob sua influência tenha recebido de seus organizadores o sugestivo título de Misterium Salutis. Compêndio de Dogmática histórico-salvífica.

Estando à clássica obra de Rosino Gibellini, intitulada La teologia del XX secolo, damo-nos conta de que as correntes teológicas emersas no século passado se colocam, todas elas sem exceção, debaixo do arco íris da História. É, portanto, no horizonte do paradigma da historicidade que se inserem todas as reviravoltas (les tournants) teológicas do século passado: tanto a existencial-antropológica como a hermenêutica e, sucessivamente, a política e, por fim, a planetária. Gibellini distingue quatro tipologias consoantes ao modo de fazer teologia no decorrer do século XX: 1) Teologias da identidade; 2) Teologias da correlação; 3) Teologias políticas; 4) Teologias na era da mundialização (GIBELLINI, 2007, p. 559-560). 
As Teologias da Identidade estariam preocupadas em afirmar a transcendência da Palavra de Deus (K. Barth) e de atestar a absoluta superioridade da Revelação cristã em relação à filosofia e à sabedoria humana em geral (H.U von Balthasar). Por essa razão, a teologia é apresentada como "dogmática eclesial" (Barth), como "gramática da fé" (Lindbeck) ou como "algo que dá o que pensar" (Jüngel).

As Teologias da correlação se caracterizariam pela articulação entre identidade e relevância no interior da teologia cristã em relação à dimensão existencial, antropológica, cultural e experiencial humana. Aqui se inscrevem as conhecidas teologias: existencial (Bultmann), da cultura (Tillich), antropológica (K. Rahner), da experiência (Schillebeeckx), ecumênica e inter-religiosa (Küng), hermenêutica (Geffré e Tracy).

As Teologias políticas (Metz, Moltmann e Sölle) representariam a passagem do antropológico existencial para a esfera do político. Nesse sentido, elas propõem que se desentranhem os conteúdos sociais e políticos da mensagem cristã, recolocando assim a fé cristã no espaço público contra toda espécie de privatismo religioso segundo os moldes das sociedades burguesas pós-iluministas.

Por fim, Gibellini considera o movimento de Ingresso da teologia na era da mundialização. E nesse rol ele elenca toda a diversidade cultural e de gênero que irrompeu no seio da teologia cristã no decorrer do século passado, a saber: TdL latino-americana, Teologia da inculturação no continente africano, a Teologia das religiões no continente asiático, a Teologia feminista. Seria o movimento do irromper das teologias do terceiro mundo no universo da teologia cristã universal.

Concluindo, diríamos que praticamente todas as teologias surgidas na área geográfica do Atlântico Norte no curso do século passado pretendem responder à questão tão bem formulada por D. Bonhoeffer: como falar de Deus ao ser humano adulto e emancipado, autêntico filho da Ilustração européia (GUTIÉRREZ, 1979, p. 546-558). Todavia, nesse mesmo século XX, emergiam outras perguntas que não 
queriam calar. Essas provinham de outras latitudes, regiões essas marcadas por relações distintas para com a Modernidade ocidental. Essas questões emergiam, para todos os efeitos, do "reverso da história".

\subsection{0 "reverso da história": perspectiva da TdL}

Uma primeira ruptura para com essa universalização do paradigma moderno da historicidade emerge no continente latino-americano na década de sessenta do século passado. A explicitação dessa nova consciência se deu durante a preparação de uma conferência de Gustavo Gutiérrez a ser proferida em Chimbote (Peru) em julho de 1968, poucas semanas antes da abertura da Assembléia dos bispos em Medellín, sobre a realidade vivida na América Latina como desafio para uma pastoral de promoção humana. O texto da conferência, publicado no ano seguinte sob o título Para una teología de la liberación, significou uma verdadeira guinada para a teologia latino-americana, pois pela primeira vez e de modo explícito, se propunha uma "teologia da libertação" em alternativa à "teologia do desenvolvimento". O próprio Gutiérrez é quem oferece um esclarecedor testemunho sobre o contexto de sua intervenção e sobre o alcance da mesma:

Para nós que tínhamos uma responsabilidade pastoral eram os anos em que nos interrogávamos sobre a presença do Evangelho e da Igreja nesta ebulição de idéias, de experiências, de correntes e buscávamos critérios de discernimento. Nessa situação se efetuou em Chimbote uma reunião de sacerdotes e leigos para tentar compreender aquilo que vivíamos em nosso país. Foi-me confiado o relatório teológico sobre um tema que era então muito discutido: a teologia do desenvolvimento. Ao preparar meu relatório compreendi que era mais bíblico e mais teológico falar de uma teologia da libertação, ao invés de uma teologia do desenvolvimento. Ou seja, teologia da libertação como teologia da salvação nas concretas situações históricas em que o Senhor nos oferece a graça da salvação (GUTIÉRREZ, 1986, p. 125-126).

Como vemos a singularidade da proposta da TdL latino-americana emerge a partir da maneira alternativa de se perceber a particularidade da realidade dos povos latino-americanos no cenário internacional. Não se aceita sem mais a 
tipologia do paradigma da historicidade segundo o qual a realidade inteira seria capturada no bojo de um único e inexorável processo histórico linear caracterizado pelo progresso e pelo desenvolvimento. Desenvolvimento tinha se tornado, naqueles idos, palavra-chave do processo de recolonização encabeçado pelas nações ricas do hemisfério norte. Falava-se em povos desenvolvidos e em povos subdesenvolvidos ou em vias de desenvolvimento.

No contexto dessa reviravolta, surgem expressões que caracterizam o dissenso quanto à linearidade totalizadora da universalidade do paradigma da historicidade: "reverso da história", "avesso da história”, “o não-homem” como interlocutor privilegiado da TdL, "Sitz im Leben und Sitz im Tode" (contexto vital e, ao mesmo tempo, contexto de morte) como lugar teológico, na dupla valência de ponto de partida e também de perspectiva da reflexão teológica.

Para salientar a peculiaridade da TdL enquanto instauradora dessa ruptura com a Modernidade clássica, Jon Sobrino introduz uma questão metodológica que nos parece esclarecedora (SOBRINO, 1976, p. 177-208). Ele distingue dois momentos no interior do Iluminismo: o primeiro se caracterizaria pela exigência da racionalidade crítica (Kant), o segundo pela exigência da práxis transformadora (Marx). A teologia européia do século passado teria se sensibilizado face às questões postas no interior do primeiro momento. Já a TdL se teria ocupado sobretudo da problemática suscitada no bojo do segundo momento. A teologia européia responderia às questões postas pela Modernidade. Questões relativas ao sentido da existência e, portanto, circunscritas ao âmbito da subjetividade e da inter-subjetividade. De outro gênero é a proposta da TdL que pretende instaurar uma relação diversa para com a realidade através de um percurso peculiar: partindo da práxis e, passando pela teoria, volta novamente à práxis. As perguntas, portanto, que a TdL quer responder derivam da própria prática vivida dentro de um processo caracterizado pelo binômio opressão/libertação. E sua intenção última é a de se constituir em uma prática teórica teológica no interior do processo mais amplo de libertação sócio-política e econômica. 
Gutiérrez, por seu turno, explicita o interlocutor privilegiado e a tarefa da teologia latino-americana na seguinte pergunta: Como falar de Deus a partir do sofrimento do inocente? Escreve ele:

De que maneira falar de um Deus que se revela como amor em uma realidade marcada pela pobreza e pela opressão? Como anunciar o Deus da vida a pessoas que sofrem uma morte prematura e injusta? Como reconhecer o dom gratuito de seu amor e de sua justiça a partir do sofrimento do inocente? Com que linguagem dizer aos que não são considerados pessoas que são filhas e filhos de Deus? (GUTIÉRREZ, 1988, p. 18-19).

É inegável o diferencial da TdL latino-americana com respeito às demais teologias do século XX. Todavia, mesmo assumindo uma postura radicalmente crítica, a TdL latino-americana não conseguiu romper de vez com o paradigma da História. Seu referencial de base continuou sendo sempre a historicidade ainda que assumisse uma perspectiva a partir do seu reverso (ELLACURÍA, 1990). Por isso chamamos a atenção acima para os imagens ou expressões mediante as quais a TdL andou demarcando suas fronteiras e identidade: avesso, reverso, nãohomem, libertação, Sitz im Leben und Sitz im Tode.

Nesse sentido, vale lembrar o que propunha J.L. Segundo, já nos inícios dessa nova teologia, no que diz respeito a uma necessidade básica para a TdL: por em movimento o círculo hermenêutico entre "libertação da teologia" e "teologia da libertação". Trata-se de um processo recíproco e, por isso mesmo, simultâneo. Esta seria, em sua opinião, condição imprescindível para libertar a teologia clássica das amarras de sua falsa consciência universal. Explorar a autonomia relativa e a constitutiva mutualidade entre "libertação da teologia" e "teologia da libertação" seria conditio sine qua non para o exercício de uma autêntica Teologia da Libertação (SEGUNDO, 1975).

As intuições básicas e a metodologia específica da TdL latino-americana foram sendo aos poucos incorporadas por outras teologias e pelo próprio 
Magistério; simultaneamente suas raízes foram se aprofundando nos terrenos específicos das minorias pobres e oprimidas do continente latino-americano e de outras latitudes (LIBANIO, 1987). Trata-se de uma expansão e consolidação mediante um processo que poderíamos chamar de "desdobramento de paradigma”. Um exemplo claro dessa atitude se observa na sensibilidade crescente de seus principais representantes com relação às questões relacionadas ao âmbito da cultura. Neste particular, a TdL colheu a ocasião das celebrações em torno dos 500 anos de evangelização do continente para prestar mais atenção aos desafios e questões provenientes sobretudo das culturas marginalizadas presentes e atuantes na formação das culturas latino-americanas e caribenhas: a cultura dos povos indígenas autóctones, a cultura afro-americana e a cultura da mulher, vítima da opressão machista. Neste sentido, a proposta de inculturar o Evangelho nas diversas culturas presentes no continente surgiu como alternativa à proposta de se criar uma cultura cristã para fazer frente à cultura moderna secular. Nos últimos anos, tem-se lançado mão de outros termos para exprimir a complexa relação envolvendo evangelho e culturas: "diálogo intercultural" ou "interculturalidade" (BRUNELLI - TAVARES, 2007). E, mais recentemente, essa pergunta foi ampliada e potencializada mediante a proposta de L. Boff de articular o grito do pobre com o grito da Terra (BOFF, 1995; 1996, p. 75-88; 2000, p. 1889-207). Proposta essa assumida e relançada contundentemente pelo papa Francisco em sua recente encíclica sobre o cuidado da casa comum, a Laudato Si’

\subsection{O intercultural como encontro e diálogo entre as culturas}

O dissenso que a Teologia intercultural manifesta para com o paradigma da Historia diz respeito a três aspectos: 1) ao programa de um mapa-mundi, que se trai como "el mapa del emperador" (HINKELAMMERT, 1998); 2) à ideia imposta e difusa de contemporaneidade; 3) à assunção de uma história particular como $a$ História universal. 


\subsubsection{O "mapa do Imperador" e a proposta de "uma nova cartografia"}

A afirmação de uma única História (com $\mathrm{H}$ maiúsculo) trai a impostura do processo de unificação das distintas temporalidades que compõem a complexidade do Tempo. Segundo essa compreensão, só haveria história dentro de um único curso, selando assim a submissão de todas as temporalidades a uma concepção única de História. E essa submissão se dá através de distintas formas. Desde a negação absoluta de histórias singulares, que não contemporizam com os interesses hegemônicos, até a submissão violenta das mesmas em função de interesses particulares. Um expediente intermediário se dá mediante hierarquizações que revelam capturas e privatizações indevidas.

O escopo de um mapa-mundi é produzir uma "cartografia" que reflita a imposição de uma concepção única e hegemônica de História. Esta "cartografia” é marcada, desde o início, pela ideologia do progresso ilimitado e pela narrativa triunfalista dos vencedores. São eles, na verdade, aqueles que projetam e produzem os mapas e, com isso, universalizam algumas tradições e regionalizam outras. Impõem nomes a uns e outros. Reduzem as paisagens particulares a meros detalhes de um mosaico desmemorizante, alheio e insensível às memórias alternativas. Numa palavra, a História se revela como uma construção constitutivamente assimétrica.

Diante de tamanha impostura, a de negar as temporalidades alternativas, colocada em prática pela concepção moderna de História, o pensamento intercultural propõe a construção urgente de "uma nova cartografia". Trata-se de uma cartografia que inclua as histórias particulares, sem qualquer programa de unificação que marginalize ou negue as diferenças específicas. Seu intento é traçar uma nova topografia do mundo em suas irredutíveis diferenças e complexidades, recuperando paisagens e sendas singulares e substituindo nomes impostos por nomes originários oriundos de contextos locais. 
$\mathrm{O}$ paradigma proposto pelo pensamento intercultural é o encontro e o diálogo entre as culturas. Pois considera ser esse o lugar privilegiado para o encontro das memórias dos povos e, também, local propício para o intercâmbio e o enriquecimento recíproco entre as várias tradições. Pois como afirma FornetBettancourt: "Não existe apenas uma pluralidade de histórias, a historicidade humana é temporalmente pluralista" (2009, p. 99).

\subsubsection{A idéia de Contemporaneidade e o postulado da simetria entre as distintas temporalidades e entre "tempos" diferentes}

O programa de universalização da História excogitado e atuado pela Modernidade ocidental produziu a idéia de contemporaneidade e de seus correlatos, a saber: "Tempo presente", "nosso tempo", "tempos atuais", "hoje", etc... Afirmações como, por exemplo, "recuperar o passo da história", "estar à altura do próprio tempo", "ser filho do próprio tempo", e outras similares, se converteram em critério irrenunciável para medir a atualidade ou o anacronismo de pessoas e instituições.

Essa noção de contemporaneidade, típica da Modernidade ocidental, encobre, mediante sedutora camuflagem, o conflito em curso entre as várias temporalidades. E esse conflito latente se vela por meio da imposição de contemporização ou de consentimento face ao programa do "nosso tempo": funcional, mercantilista, midiático (FRAISSE, 2007). O pensamento intercultural desmascara esse programa de contemporização e de consentimento executado pela Modernidade ocidental, mediante a recuperação daquelas temporalidades outras que são reprimidas por meio de expedientes sutis: regionalização, inferiorização, privatização, captura e negação.

O caráter alternativo destas temporalidades constitui uma reserva de sentido a partir da qual submeter à avaliação crítica o conceito de contemporaneidade. O crucigrama em vez da linha do tempo, talvez fosse, nesse 
caso, a imagem mais apta para exprimir o encontro e o diálogo entre as várias temporalidades que se cruzam e se encontram numa espécie de ciranda epistemológica.

Há, todavia, memórias e tradições culturais que não se submetem à linearidade do tempo histórico. Semelhante constatação nos põe diante de uma inevitável questão: não seria a história linear estreita demais para abarcar a complexidade e o devir da existência humana e da vida em geral? (ROSENZWEIG, 2005). Nesse preciso contexto e, portanto, ciente das inúmeras questões que daí provêm, o pensamento intercultural propõe não apenas o diálogo entre as diversas temporalidades inscritas no arco do tempo linear e progressivo, mas também o diálogo entre os tempos, nesse caso específico, entre o tempo histórico, o tempo cíclico e o tempo cosmológico. Várias culturas testemunham o fato de que para elas o evento fontal, e não apenas fundacional, se dá para além da idéia de tempo proposta pela história segundo os parâmetros da linearidade progressiva (ELIADE, 1979; PANIKKAR, 1967; 1993; 1999 e 2005). Essas culturas continuariam excluídas do encontro e do diálogo por não se inscreverem dentro dos estreitos limites da linearidade histórica ocidental?

\subsubsection{Da captura do evento pelo logos ao autrement que l'histoire}

Uma análise mais profunda da História, paradigma hegemônico da Modernidade ocidental, revela a vontade de poder e de captura do logos em relação à vida como evento. A História, em última instância, é uma grande composição racional, uma verdadeira tessitura, feita pelo logos em seu afã de poder e controle sobre a realidade. Nesse sentido, a História emerge como o cenário do grande espetáculo do submetimento racional da realidade pelo logos. Ou ainda da captura da realidade pelo poder dominador e possessivo do logos. 
O emergir da História no ocidente coincide com o processo através do qual o logos moderno vai plasmando seu senhorio sobre os acontecimentos históricos no intuito de instaurar uma razão interna para a história. Se há razões que justificam e conduzem a história então o logos se encontra seguro e precavido face ao caráter inusitado e imprevisto dos acontecimentos. Estão criadas as premissas para se falar, com propriedade, de uma História (com H maiúsculo). Por essa razão, foi possível a Hegel dizer que tudo o que é real é racional e vice e versa (ROSENZWEIG, 2005; LÉVINAS, 1961). Não se trata, obviamente, de negar nem de diminuir a importância e o alcance da historicidade no complexo da cultura ocidental. Trata-se, porém, de reconhecer que, segundo Fornet-Bettancourt "a violência da ontologia e do logos se prolonga e se concretiza hoje na violência histórica de uma historicidade particular que foi universalizada" (2009, p. 102).

O pensamento intercultural não é avesso à idéia de universalidade. Ele não propõe a fragmentação do mundo nem faz apologia de regionalismos ou de provincianismos. O que postula o pensamento intercultural é uma universalidade a partir das diferenças culturais. A diversidade cultural não compromete nem inviabiliza a universalidade. A perspectiva do encontro e do diálogo é que possibilita, em última instância, a verdadeira universalidade. Pois a autêntica experiência de universalidade brota das experiências particulares e locais. Há uma comunicação que se dá pelas raízes, a partir de baixo, e por isso verdadeiramente inclusiva. Não existe universalidade desvinculada dos processos locais e particulares, posto que o universal não se dá separado do local nem tampouco contraposto ao particular. Qualquer tentativa de universalização que não brote das particularidades de cada situação e das diferenças de cada realidade local resultará fruto de imposição e de impostura. Uma concepção de universalidade que não brote do encontro e da partilha das diferenças se degenerará em uma mera tautologia.

A partir, portanto, do encontro e do diálogo entre as várias culturas é que se poderão criar condições para que haja experiências de universalidade inclusiva 
capazes, por sua vez, de produzirem uma nova cartografia cultural. Trata-se da proposição de uma universalidade temporalmente pluralista. Daí a necessidade de se postular, parafraseando Lévinas, algo na linha do autrement que l'histoire ${ }^{2}$.

\section{Por uma transformação intercultural da teologia}

Com base em tudo o que foi dito até agora, poderíamos concluir pela necessidade de uma transformação intercultural da Teologia. Em que consistiria semelhante transformação? Em primeiro lugar, advertimos a necessidade de estabelecer os limites e a diferença entre Teologia da Interculturidade e Teologia intercultural.

Uma eventual Teologia da Interculturalidade não garantiria o que propomos como transformação intercultural da teologia. Ela seria mais uma entre tantas expressões do que se convencionou chamar de "teologias do genitivo". Nesse caso, a interculturalidade, genitivo objetivo, seria considerada o objeto material da teologia. Em outros termos, a teologia se ocuparia da interculturalidade considerando-a objeto de estudo ou pesquisa e nada mais que isso. Em suma, a interculturalidade se reduziria a um tema a mais entre tantos outros pesquisados pela teologia.

\subsection{0 intercultural como "lugar teológico"}

Insistimos aqui na necessidade de uma transformação intercultural da teologia e, por isso mesmo, falamos de uma teologia intercultural. O intercultural, nesse caso, constituiria o objeto formal da teologia, incidindo sobre seu método específico e, ao fim e ao cabo, sobre a especificidade da teologia como ciência. O objeto formal é aquilo que faz a teologia assumir-se como ciência singular e, portanto, diferente das outras ciências. É, em suma, o que a distingue das outras

\footnotetext{
${ }^{2}$ Trata-se de uma paráfrase à conhecida obra de Lévinas intitulada Autrement que l'être ou au delà de l'essence (1974).
} 
ciências. E, enquanto tal, o intercultural se torna, para todos os efeitos, "lugar teológico", compreendido como ponto de partida e, ao mesmo tempo, como perspectiva da teologia propriamente dita.

Assim compreendida, a teologia intercultural não se limita simplesmente a afirmar ou a constatar a pluralidade das culturas. Ela salienta que seu lugar teológico é constituído pela pluralidade de culturas em comunicação. Esse é precisamente seu momento "inter". Trata-se de uma teologia elaborada a partir do contexto do encontro e do diálogo entre as culturas e sob sua perspectiva.

Como entender a afirmação do "intercultural” como lugar teológico em sua relação com os clássicos loci theologici, a saber, a Escritura, a tradição, o magistério, as sentenças teológicas, entendidos como "fontes" da teologia? Lugar teológico, aqui, não deve ser concebido no sentido dos clássicos loci theologici de Melchior Cano, mas no sentido daquele lugar a partir do qual e sob a regência do qual os clássicos lugares teológicos da teologia são potencializados ao máximo e, portanto, podem oferecer o melhor de si. O "intercultural", portanto, não seria apenas lugar de compreensão dos dados transmitidos pela tradição através das fontes do conhecimento teológico, mas converte-se no lugar no qual e a partir do qual esses dados oferecem o melhor de si.

É nesse sentido que o intercultural emerge como um método de transformação da teologia em seu processo mesmo de constituição. O intercultural é assumido, portanto, como lugar e método privilegiados para se repensar todos os conteúdos e disciplinas teológicos, incluindo a teologia da cultura.

A assunção do intercultural como lugar teológico provoca uma mútua fecundação no processo mesmo de constituição do discurso teológico. Pois, ao se tornar perspectiva e método a partir dos quais a teologia interpreta as realidades e os temas que configuram o mundo em que vivemos, o intercultural também se torna, simultaneamente, perspectiva e método a partir dos quais repensar e reavaliar continuamente seu processo mesmo de constituição enquanto teologia 
cristã. Ademais, o encontro e o diálogo entre as culturas, na perspectiva do intercultural, revelam as preferências culturais que constituem as referências fundamentais que mais incidem no processo mesmo de elaboração do discurso teológico nas suas dimensões constitutivas, a saber: teórica, metodológica e ética.

\subsection{A compreensão do momento inter a partir do intercultural}

O momento inter suscita um campo semântico, no mínimo, instigante. Ele poderia também ser expresso pela metáfora da fronteira. A partir de seu sentido primeiro e literal, qual seja o de limitação de uma área geográfica, a imagem da fronteira nos remete a um sentido figurado de contorno de espaços imaginários. A imagem de fronteira pressupõe ambientes separados (ou ligados) por uma linha fronteiriça. A mesma linha que, a princípio separaria, pode se tornar a condição de possibilidade de toda e qualquer comunicação ou relação. $\mathrm{O}$ escritor moçambicano Mia Couto talvez nos ajude a imaginar o que significaria a metáfora da fronteira, ou do momento inter, no contexto de um projeto que tem por escopo repensar o pensamento. O trecho dele que citamos é retirado de sua obra intitulada, justamente: Repensar o pensamento, redesenhando fronteiras. Escreve Mia Couto:

Nosso pensamento, como toda a entidade viva, nasce para se vestir de fronteiras. Essa invenção é uma espécie de vício de arquitetura: não há infinito sem linha do horizonte. Desde a mais pequena célula aos organismos maiores, o desenho de toda a criatura pede uma capa, um invólucro separador. A verdade é esta: a vida tem fome de fronteiras. É assim que se passa e não haveria nada a lamentar. Porque essas fronteiras da natureza não servem apenas para fechar. Todas as membranas orgânicas são entidades vivas e permeáveis. São fronteiras feitas para, ao mesmo tempo, delimitar e negociar. O "dentro" e o "fora" trocam-se por turnos (COUTO, 2014). 


\subsection{A compreensão de cultura a partir do intercultural}

Para sermos breves, diríamos que o que aqui entendemos por cultura se situa entre o multiculturalismo e o transculturalismo. Para sermos mais exatos: para além do multiculturalismo e aquém do transculturalismo.

Para além do multiculturalismo porque a teologia intercultural não quer apenas organizar a simetria harmônica entre as várias culturas nem gerir as relações existentes entre todas elas. E aquém do transculturalismo porque não comunga da suspeita de que a interação entre as várias culturas conduza espontânea e necessariamente à dissolução das culturas e suas referências identitárias. Em outras palavras, o encontro e o diálogo entre as culturas não se deteriora numa espécie de hibridismo cultural nem muito menos em uma mescla insípida (GARCÍA CANCLINI, 1989).

O fomento da convivência intercultural a partir do respeito e da afirmação da coexistência entre as várias culturas pode tornar possível a emergência de singularidades contextuais e locais desconhecidas. É na convivência com os diferentes que podem emergir as singularidades ainda não conhecidas. Ao situarse além do multiculturalismo e, ao mesmo tempo, aquém do transculturalismo, a teologia intercultural quer evitar uma dupla tentação ou risco: a criação de culturas extáticas e monolíticas, fechadas em si mesmas e a defesa de culturas globalizadas onde as identidades são totalmente diluídas.

Outra conseqüência positiva do encontro e diálogo entre as várias culturas é a instauração do momento da crítica e da correção recíprocas entre as várias culturas em diálogo. É a experiência de que o intercultural pode se transformar também no intracultural. Nesse caso, não se limita simplesmente a refazer o mapa das fronteiras entre as culturas, afirmando as diferenças, mas reconstituindo a própria casa, mediante a recuperação das singularidades de cada cultura, umas a partir das outras. 


\section{Conclusão}

Habitamos um mundo extremamente complexo. Constatamos, ademais, uma situação de indigência do pensamento que acolita a complexidade das relações do mundo em que vivemos. Não nos interessa mais o conhecimento como busca de sentido, mas sim o conhecimento aplicável. Trata-se da redução do logos à sua dimensão tecno-lógica (téchne + logos). Testemunha-se, portanto, a hegemonia da razão instrumental que, por sua vez, produz um processo duplo e simultâneo de desumanização e de desnaturalização. Em seu exercício, opera-se a tradução dos fins em resultados, a redução do mistérico ao enigmático e, enfim, a submissão do inusitado e imprevisível à ordem da previsão. A própria concepção de verdade se encontra, no "mundo da tecnologia", condicionada pela noção de eficiência. A verdade da técnica é, para todos os efeitos, funcional.

Por essa razão a palavra-chave para exprimir o que se compreende hoje por conhecimento é Know how (conhecer/saber como), portanto, um conhecimento aplicável, um saber-como fazer, um saber que se esgota no instrumental. Não apenas um saber apto a produzir receitas, moldes de leitura e instrumentos para intervir na realidade. A situação é ainda mais grave, descobrimo-nos reféns de um saber que se concebe a si próprio como instrumento. É claro que um saber assim concebido não alcança as questões que vão além da utilidade e da aplicabilidade. Esse saber se revela, para todos os efeitos, vítima de uma indigência. Ele não consegue problematizar em profundidade as questões que constituem o horizonte de fundo do cenário atual.

Em que medida a Teologia intercultural poderia nos ajudar a superar esse impasse em meio ao qual nos encontramos e nos libertar dessa espécie de indigência do pensamento? A teologia intercultural pode reviver em nós aquela originária experiência do conhecer como nascer junto e, portanto, reconhecer as coisas a partir de uma relação constitutiva e vital nossa para com as mesmas. Conhecer, de fato, vem do Latim cum+nascere (nascer junto) que deu origem ao 
verbo connaître em Francês. Pode levar-nos ainda a recuperar o verdadeiro sentido da compreensão como articulação entre as várias dimensões que compõem a complexidade do real: um saber inclusivo tecido ponto por ponto mediante os movimentos recíprocos e complementares da distinção e da conjunção. Pode, enfim, conduzir-nos à redescoberta do sentido mais originário do pensar como curar. De fato, pensum em Latim era uma espécie de ungüento que se colocava sobre a ferida para protegê-la e, ao mesmo tempo, curá-la; o verbo francês penser conservou as ressonâncias etimológicas do pensum latino, pois significa pensar, mas, também, cuidar e curar. E, neste sentido, acena para a dimensão ética de todo raciocínio e conhecimento humanos. Pensa-se e reflete-se não apenas com o intuito de especular dando, assim, asas à curiosidade, mas, ao contrário, pensa-se com a intenção de remediar e de curar as feridas abertas de nossa realidade humana, histórica e cósmica.

Em outras palavras, poderíamos falar não mais de um saber como poder, poder este predatório e perverso, mas, agora, nesta nova estação, de um saber cuidar, de um aprender a conviver com as demais criaturas. Trata-se, em suma, de uma autêntica re-significação do poder através do aprender a cuidar (BOFF, 2012). Não mais um saber que oferece a ilusória impressão de gerar certeza e segurança, mas, ao contrário, um saber peculiar que se revela sensível à dinâmica do aprender a lidar com as incertezas e a cuidar de si, dos outros e da complexidade das criaturas como maneira singular de conviver e de cuidar da vida.

Outra contribuição da Teologia intercultural a essa indigência do pensamento atual poderia ser estimular-nos à ousada, porém imprescindível, tarefa de habitar poeticamente o mundo (TAVARES, 2014, p. 13-24). Habitar o mundo é decisão que diz respeito, em modo próprio, ao ser humano e somente a ele. Os demais seres vivos, dotados de instinto natural, não habitam, eles são integrados ao ambiente que lhes é dado de antemão. As outras espécies possuem todas, sem exceção, cada qual seu nicho ecológico. Por não ter um ambiente próprio, perfeitamente adaptado a ela, a espécie humana experimenta uma 
imperiosa necessidade vital: construir para si mundos como condição de sua própria sobrevivência. E esses mundos, o ser humano os constrói, sobretudo, na mediação da Linguagem.

A teologia se encontra, hoje, em condições de provocar-nos à decisão de habitar poeticamente o mundo? A teologia cristã é evento de Linguagem. Nossa civilização é comumente caracterizada como nïlista. A relação com a linguagem, hoje, parece ter-se invertido. Encontramo-nos enredados em um monólogo funcionalista que confunde verdadeiro com eficiente. Comportamo-nos como se fôssemos criadores e manipuladores da linguagem. A experiência do sentido parece ter-nos escapado por entre os dedos. Tornamo-nos incapazes de colher a Linguagem em sua expressão soberana: interpelação que nos provoca à escuta atenta e à generosa disponibilidade. Um dos escopos da Teologia intercultural não seria justamente o de provocar-nos à rememoração dessas dimensões?

\section{REFERÊNCIAS}

ASSMANN, H.; HINKELAMMERT, F. A idolatria do Mercado. Ensaio sobre economia e teologia. São Paulo: Paulinas, 1989.

BAUMAN, Z. Vida para consumo. A transformação das pessoas em mercadoria. Rio de Janeiro: Zahar, 2008.

BOFF, L. Ecologia: Grito da Terra, Grito dos pobres. São Paulo: Editora Ática, 1995.

BOFF, L. Da libertação e ecologia: desdobramento de um mesmo paradigma. In: ANJOS, M.F. (org.). Teologia e novos paradigmas. São Paulo: Paulinas, 1996. p. 75-88.

BOFF, L. O pobre, a nova cosmologia e a libertação - como enriquecer a Teologia da Libertação. In: SUSIN, L.C. (org.). Sarça ardente. Teologia na América Latina: Prospectivas. São Paulo: Soter/Paulinas, 2000. p. 189-207.

BOFF, L. O cuidado necessário. Na vida, na saúde, na educação, na ecologia, na ética e na espiritualidade. Petrópolis: Vozes, 2012.

BRUNELLI, D. - TAVARES, S. Evangelização e Interculturalidade. Petrópolis: Vozes/ITF, 2010. 
CHENU, M.-D. Une école de théologie: le Saulchoir. Paris: Cerf, 1937.

CHENU, M.-D. La Parole de Dieu. 1. La foi dans l'intelligence; 2. L'Èvangile dans le temps. Paris: Cerf, 1964.

COUTO, M. Repensar o pensamento, redesenhando fronteiras. Disponível em: [HTTP://fronteiras.com/canalfronteiras/entrevistas/?16,76]. Acesso em 7 de julho de 2015 .

DANIÉLOU, J. Les orientations présentes de la pensée religieuse. Études, Paris, v. , p. 521, avril 1946.

ELIADE, M. El mito del eterno retorno. Madrid: Alianza Editorial, 1979.

ELLACURÍA, Ig. Filosofía de la realidad histórica. San Salvador: UCA Editores, 1990.

FORNET-BETANCOURT, R. Tareas y propuestas de la Filosofía Intercultural. Aachen: Mainz Verlag, 2009.

FRAISSE, G. Du consentement. Paris, Seuil; Kensey, 2007.

GALIMBERTI, U. Psiche e techne. O homem na idade da técnica. São Paulo: Paulus, 2006.

GARCÍA CANCLINI, N. Culturas híbridas. México: Grijalbo, 1989.

GIBELLINI, R. La teologia del XX secolo. Brescia: Queriniana, 1992.

GUTIÉRREZ, G. Os limites da teologia moderna. Um texto de Bonhöffer. Concilium, Petrópolis, v. 15, p. 546-558, 1979.

GUTIÉRREZ, G. Non possiamo fare teologia in un' angolo morto della storia, In: GIBELLINI, R. Il dibattito sulla teologia della liberazione. Brescia: Queriniana, 1986, p. 125-126.

GUTIÉRREZ, G. Hablar de Dios desde el sufrimiento del inocente. Una reflexión sobre el libro de Job. Salamanca: Sígueme, 1988.

HINKELAMMERT, F. El mapa del emperador. San José: DEI, 1998.

KUHN, Th. A estrutura das revoluções científicas. São Paulo: Perspectiva, 1996.

LÉVINAS, E. Totalité et infini. Essai sur l’éxteriorité. La Haye: Nijhoff, 1961.

LÉVINAS, E. Autrement que l'être ou au delà de l'essence. La Haye, Nijhoff, 1974. 
LIBANIO, J.B. Teologia da Libertação. Roteiro didático para um estudo. São Paulo: Edições Loyola, 1987.

LIPOVETSKY, G. O império do efêmero. A moda e seu destino nas sociedades modernas. São Paulo: Companhia das Letras, 2006.

MOREIRA, A. (Org.). O capitalismo como religião. Goiânia: Ed. da PUC Goiás, 2012.

MOREIRA, A.; LEMOS, C.T.; QUADROS, E.G. (Orgs.). A religião da mídia e a mídia da religião. Goiânia: Ed. da PUC Goiás - Gráfica e Editora América, 2012.

MO SUNG, Jung. Idolatria do capital e a morte dos pobres. São Paulo: Paulinas, 1989.

PANIKKAR, R. Técnica y tiempo. Buenos Aires: Columba Pinch, 1967.

PANIKKAR, R. La nueva inocencia. Estella: Verbo Divino, 1993.

PANIKKAR, R. La intuición cosmoteándrica. Madrid: Trotta, 1999.

PANIKKAR, R. De la mística. Barcelona: Herder, 2005.

POLANYI, Karl. A grande transformação. As origens da nossa época. Rio de Janeiro: Campos, 2000.

ROSENZWEIG, F. La stella della redenzione. Milano: Vita e Pensiero, 2005.

SEGUNDO, J.L. Liberación de la teología. Buenos Aires: Ed. Carlos Lohré, 1975.

SOBRINO, J. El conocimiento teológico en la teologia europea y latinoamericana. In: AA. VV. Liberación y cautiverio. Debates en torno al método de la Teologia em América Latina, Ciudad de México: 1976, p. 177-208.

TAVARES, S. Entre a cruz e a espada: religião no mundo da tecnociência, do mercado e da mídia. Horizonte, Belo Horizonte, v. 12, p. 382-401, abr./jun. 2014

TAVARES, S. Ecologia: um novo paradigma. In: TAVARES, S.; BRUNELLI, D. Evangelização em diálogo. Novos cenários a partir do paradigma ecológico. Petrópolis: Vozes/ITF, 2014. p. 13-24. 